\title{
Error Analysis of English Sentences Written by Indonesian \\ College Students
}

\author{
Ahmad Burhanuddin \\ Fakultas Tarbiyah dan Ilmu Keguruan, IAIN Pekalongan, Indonesia \\ ahmad.burhanuddin@iainpekalongan.ac.id
}

DOI: $10.20884 / 1 . j 11.2020 .11 .1 .2154$

\begin{abstract}
Article History:
First Received:

ABSTRACT

$27 / 11 / 2020$

This study aims to investigate (1) the pattern of the errors made by the

Final Revision: Indonesian students (2)the dominant errors(3) the impact of the errors. Designed as qualitative research this research involved 100 students of the

$09 / 06 / 2020$

Available online: second year of the English Department IAIN Pekalongan. The data were collected through an open-ended questionnaire as the instrument of this study. The research findings reveal that (1) the patterns of the errors are spread into eleven types of errors, including verbs, articles, spelling,

$25 / 06 / 2020$ adjectives, preposition, sentence structure and ordering, word formation, word selection, noun, pronoun, and ambiguous communication; (2) $55.28 \%$ of the errors are in terms of subject-verb agreements, the use of articles $(9.76$ $\%)$, and misspelling $(8.94 \%)$. These findings illustrate that most of the students did not know how to use verb and articles correctly and they need to pay attention to the spelling of the English words; (3) the errors found in the sentences give some ambiguities to the meaning of the sentences.
\end{abstract}

Keywords: error analysis; written text; subject-verb agreement; ambiguity

\section{INTRODUCTION}

Grammar is not the only aspect that must be considered when making sentences, but grammar is the most important aspect to check first before looking at other aspects, such as word choice or relationship between paragraphs. Information from educators about mistakes in making sentences of their students will be able to improve the aspects of accuracy and fluency in writing (Daniel. (2003). The teacher is expected to consistently remind students of the mistakes made when writing to avoid repeating the same mistakes.

Previous studies suggested that the errors made by students in their writing were mostly dealing with verbs. The percentage of errors made by the pupils in the four word class is 79 per cent and 77 per cent for nouns, 97.4 per cent and 92.3 per cent for verbs, 23.7 per cent and 7.7 per cent for prepositions, and 15.8 per cent and 33.3 per cent for articles. From the findings, it is obvious that verb is a problem for these pupils especially in the use of tenses. It shows that 
pupils' knowledge in the use of tenses needs to be reinforced (Yasmine, 2019). Students often make errors in terms of vocabulary, use of prepositions, and incomplete sentences (Dina. (2019). There are eight types of errors were extracted as the following: errors in word usage, articles, preposition, conjunction, tense, errors in word order active-passive structure and subject-verb agreement. Among these, errors in word usage received the highest frequency (36.2\%) and the least frequent common error was related to subject-verb agreement $(0.7 \%)$ (Salehi, 2018).

A number of research studies, as a result, have been conducted both to find out causes of writing problems and to help EFL learners overcome difficulties in their writing. For instance, some studies try to identify types of errors in learners'various types of writing, including sentences, paragraphs, essays, and abstracts, and categorize those errors, so they can be accurately corrected (Huang, 2006; Hengwichitkul, 2006; Jenwitheesuk, 2009;Bumroongthai, 2011; Lui, 2013; Runkati, 2013; Zheng \& Park, 2013; Rattanadilok Na Phuket \& Othman, 2015).

Some studies attempt to examine sources of errors since knowing the sources that lead to learners' making of theerrors is an effective way to help reduce errors (Penny, 2001; Bennui, 2008; Heydari \& Bagheri, 2012; Watcharapunyawong \& Usaha, 2013; Hinnon, 2014). Furthermore, a considerable number of studies employsome approaches to improve learners' writing skill (Presada \& Bradea, 2014; Zafar, 2016).

Kanyakorn Sermsook in his study found that errors that occur in sentences made by English students in Thailand are found in punctuation, spelling, capitalization, suitability of the subject with verbs, and compound sentences. These errors arise due to factors of knowledge of English grammar, cross-language understanding, and carefulness in making sentences (Sermsook, 2017). Errors in making sentences in English made by students of the Kick + an English STKIP Bina Bangsa include spelling, capitalization, punctuation, tenses, word order and clauses. Causes of errors include a lack of understanding of the use of tenses and carelessness in writing, resulting in errors in capitalization and punctuation (Wahyuni, 2014). The sentences in English made by high school students in grade 1 in Banda Aceh, Indonesia contain errors in making compound sentences, the use of commas that are not appropriate, the absence of sentence subjects, the absence of verbs, and the absence of the main sentence and/or clauses in compound sentences (Ananda, 2014). 


\section{Error Analysis}

Error Analysis (EA) is a method for analyzing errors made by English learners both as a foreign language (EFL/ English as a Foreign Language) and as a second language (ESL/ English as the Second Language). This method, besides being useful to help English learners to find out their mistakes, also to help teachers recognize the difficulties of their students in learning, so as to improve the teaching methods provided.

Error Analysis is an analysis by comparing what students have learned with what they have not mastered / know. Besides, the explanation given is expected to be able to reduce these errors in the future (James, 1998). Error Analysis is a study of the native language forms of speakers that differ from the structure of the language being studied (English) (Crystal, 1999). According to Corder quoted by Mungungu, Error Analysis has two objectives: 1) theoretical goals regarding what and how a person learns language, and 2) practical goals are how to help someone learn languages using the knowledge they have (Mungungu, 2010).

\section{Classification of Error}

In language learning, Error Analysis studies the types and causes of language errors. In general, language errors can be classified as follows. Corder classifies errors including: 1) missing sentence elements needed; 2) element addition is not required; 3) improper selection of sentence elements; 4) and errors in the placement of the order of sentence elements (Corder, 1981).

According to Dulay, Burt and Krashen there are six categories: 1) removal of grammatical morphemes; 2) the use of double semantics; 3) use of irregular rules; 4) use of tenses; 5) alternating use of two or more forms; 6) word order (Dulay, 1982).James classifies errors into five categories including: 1) grammatical errors (adjectives, adverbs, articles, nouns, possession, pronouns, prepositions and verbs); 2) substance errors (capitalization, punctuation and spelling); 3) lexical errors (word formation and word selection), 4) syntactic errors (coordination / subordination, sentence structure and ordering), and 5) semantic errors (ambiguous communication and miscommunication) (James, 1998).

\section{Cause of Error}

A number of linguists formulated several causes of error in making sentences. Richards mentioned two main causes of errors, namely interlingual errors and intralingual errors. The first 
is, mistakes occur when the sentence maker incorrectly applies the rules of the grammar of the mother he masters into English. Whereas the second is, sentence makers understand incorrectly or lack understanding of English grammar (Richards, 1974).

Next, Runkati (2013) and Rattanadilok Na Phuket and Othman (2015) also found two causes of error, interlingual interference and intralingual interference. Another linguist, Hinnon (2014) found three causes of error, namely negative transfer of the mother tongue (the process of translating from mother tongue to inappropriate English), limited knowledge of the target language (limited knowledge of English), and the difference between words and sentence structures of the mother tongue and those of the target language (differences in the vocabulary and sentence structure of the mother tongue with English) (Sermsook, 2017).

This research in general will look at the extent of the ability to make sentences in English, and specifically will analyze the errors that arise in those sentences. The students to be studied are second year students who have studied English for at least seven years, starting from junior high school. This study aims (1) to investigate the pattern of the errors made by second year students majoring in English Education Department of IAIN Pekalongan in making written sentences (2)to find out dominant errors made by second year students majoring in English Education Department of IAIN Pekalongan in making written sentences (3)to investigate whether the errors affect the message the sentences want to convey.

\section{MATERIALS AND METHOD}

This research is a field research by using a qualitative approach. The study was conducted in the course of Grammar in Written Text which was offered by the English Education Department, the Faculty of Tarbiyah and Teacher Training, IAIN Pekalongan in the academic year of 2019/2020.To obtain the information regarding errors frequently made by the participants, 104 pieces of their written work were collected. To seek for sources of errors, questionnaires and individual/ group interview were employed. Previous studies related to sources of errors in writing were also analyzed.

The participants of the study were 100 second year English major students in an Indonesian university. All of them have learned English as a foreign language for at least seven years. All of the 104 pieces of the students' written work were marked by the researcher. Each sentence was examined word by word. Each error was recorded according to its type in an individual error record form. 
The data analysis procedure consisted of two stages according to the purposes of the study. First, all of the collected errors were analyzed and labeled according to the types of errors to get the frequency and the percentage. Then each error type was classified into two main groups: The sentential level errors and the word level errors. Additionally, the characteristics of the errors, such as omission and addition were identified. Secondly, to seek for major sources of the errors, the information from the questionnaires and the interview was interpreted and analyzed. Moreover, previous research pertaining to sources of errors was studied.

\section{RESULTS \& DISCUSSION}

From the data collected through the questionnaires, the results are the following.

Table 1. Grammatical errors seen from types of sentences

\begin{tabular}{lllll}
\hline No. & Types of Sentences & $\begin{array}{l}\text { Grammatically } \\
\text { Correct }\end{array}$ & $\begin{array}{l}\text { Grammatically } \\
\text { Incorrect }\end{array}$ & Total \\
\hline 1. & Simple Sentences & 64 & 33 & 97 \\
2. & Compound Sentences & 59 & 37 & 96 \\
3. & Complex Sentences & 41 & 53 & 94 \\
\hline Total & & 164 & 123 & 287 \\
\hline
\end{tabular}

From 100 students given questionnaires, 287 sentences were collected. These sentences consisted of 97 simple sentences, 94 compound sentences, and 94 complex sentences. After the analysis of errors, of the total 287 sentences, 164 (57.14\%) sentences are grammatically correct, and $123(42.86 \%)$ sentences are grammatically incorrect. Of the total 123 grammatically incorrect sentences 33 (26.83\%) errors are found in simple sentences, 37 (30.08\%) in compound sentences, and 53 (43.09\%) in complex sentences.

Table 2. Type of errors occurs in the written sentences

\begin{tabular}{llllll}
\hline No. & Types of Error & \multicolumn{3}{c}{ Types of Sentences } & Total \\
\cline { 3 - 5 } & $\begin{array}{c}\text { Simple } \\
\text { Sentences }\end{array}$ & $\begin{array}{c}\text { Compound } \\
\text { Sentences }\end{array}$ & $\begin{array}{c}\text { Complex } \\
\text { Sentences }\end{array}$ & \\
\hline 1. & Adjectives & & 1 & 6 & $\mathbf{7}$ \\
\hline 2. & Adverbs & & & 1 & $\mathbf{1 2}$ \\
\hline 3. & Articles & 8 & 3 & & $\mathbf{1}$ \\
\hline 4. & Nouns & 1 & & & \\
\hline 5. & Possession & & 1 & & \\
\hline
\end{tabular}




\begin{tabular}{llllll}
\hline 6. & Pronouns & & & & $\mathbf{1}$ \\
\hline 7. & Prepositions & 2 & 2 & 2 & $\mathbf{6}$ \\
\hline 8. & Verbs & 18 & 22 & 28 & $\mathbf{6 8}$ \\
\hline 9. & Capitalization & & & & $\mathbf{3}$ \\
\hline 10. & Punctuation & & 1 & 2 & $\mathbf{1 1}$ \\
\hline 11. & Spelling & 3 & 1 & 7 & $\mathbf{3}$ \\
\hline 12. & word formation & & 3 & & $\mathbf{3}$ \\
\hline 13. & word selection & & 1 & 2 & $\mathbf{5}$ \\
\hline 14. & $\begin{array}{l}\text { coordination } \\
\text { subordination }\end{array}$ & $/$ & & & $\mathbf{1}$ \\
\hline 15. & $\begin{array}{l}\text { sentence structure } \\
\text { ordering }\end{array}$ & and & & 5 & $\mathbf{1 2 3}$ \\
\hline 16. & $\begin{array}{l}\text { ambiguous } \\
\text { communication }\end{array}$ & & 1 & & \\
\hline 17. & Miscommunication & & $\mathbf{3 7}$ & $\mathbf{5 3}$ & \\
\hline Total & $\mathbf{3 3}$ & &
\end{tabular}

Regarding the types of error, the table shows that of the 123 errors, most of them are in terms of the use of verb which is $68(55.28 \%)$, followed by the use of articles which is 12 $(9.76 \%)$ errors, and then $11(8.94 \%)$ spelling errors. Other two big errors are found in terms of the use of adjectives which is 7 (5.69\%) errors and the use of preposition which is $6(4.88 \%)$. Other types of errors are found in small percentage including errors in terms of sentence structure and ordering, word formation, word selection, noun, pronoun, and ambiguous communication.

\section{Pattern of Errors}

Even though the correct sentences are 164 (57.14\%), which is bigger than the 123 incorrect ones $(42.86 \%)$ of the total 287 sentences collected, this number indicates that the almost half of the students do not fully use the grammar correctly. This number cannot be considered small, yet in fact it is big, and thus requires a serious attention. This problem becomes more serious considering the students have studied English for almost seven years since they were in Junior High School. Therefore, identifying the pattern of the errors will be significantly useful as it can reduce the future potentials errors.

The 123 sentences are grammatically incorrect with various types of errors. The top five error patterns are in terms of verbs, articles, spelling, adjectives, and preposition. The other errors include sentence structure and ordering, word formation, word selection, noun, pronoun, and ambiguous communication. 
The findings above are in line with many theories discussed in the literature. According to James, there are 5 categories of error that often occurs in writing English sentences. 1) grammatical errors (adjectives, adverbs, articles, nouns, possession, pronouns, prepositions and verbs); 2) substance errors (capitalization, punctuation and spelling); 3) lexical errors (word formation and word selection),4) syntactic errors (coordination / subordination, sentence structure and ordering), 5) semantic errors (ambiguous communication and miscommunication).

\section{Subject Verb Agreement}

The first rank error is the subject-verb agreement which is a common error found in Thai EFL students' writing (Jenwitheesuk, 2009; Bumroongthai, 2011; Runkati, 2013; Rattanadilok Na Phuket \& Othman, 2015). It is anerror frequently made by other EFL students from other different countries (Huang, 2006; Wu \& Garza, 2014).In order for a sentence to be grammatically correct, the subject and verb must both be singular or plural. In other words, the subject and verb must agree with one another in their tense. If the subject is in plural form, the verb should also be in plural form (and vice versa).

The following examples demonstrate the writers' confusion about the rules of the subjectverb agreement.

Riri go to campus.

The sentence is incorrect because the subject is singular, but the verb is plural. The correct sentence should be Riri goes to campus.

Doni kick the ball.

The sentence is incorrect because the subject is singular, but the verb is plural. The correct sentence should be Doni kicks the ball.

I serves some foods, for my friends come at home.

The sentence is incorrect because the subject is plural, but the verb is singular. The correct sentence should be I serve some foods, for my friends come at home.

In other sentences, the errors are due to the inconsistent tense. For example,

I go to the party last night.

The sentence is incorrect because the time marker indicates a past event (last night), but the verb is present simple. The correct sentence should be I went to the party last night.

I went to the market before you come to my home. 
The sentence is incorrect because the main clause uses past simple (went), but the subordinate clause uses present simple (come). The correct sentence should be I went to the market before you came to my home.

Other errors in terms of verbs are due to the misuse of be. For example,

My parents was discuss about the current of political situation.

The sentence is incorrect because be (was) is followed by a present simple word (discuss). The be in this sentence is unnecessary or should be followed by either past participle or present continuous verbs. The correct sentence should be:

(1) My parents discussed about the current of political situation.

(2) My parents were discussed about the current of political situation.*

(3) My parents were discussing about the current of political situation.*

Sentence a is syntactically and semantically correct, meaning the parents did something and finished it in the past. Sentence b is syntactically correct, but semantically incorrect since were discussed is a passive voice, thus an agent is required. For instance My parents were discussed by my school principle. Sentence $\mathrm{c}$ is semantically correct, but syntactically incorrect since the use of past continuous indicates an action happened while another action was in progress in the past. This sentence requires another clause to make it syntactically correct. For instance, My parents were discussing about the current of political situation when I came home.

\section{Articles}

Articles were found to be errors in the second rank made by the participants. This group of students got confused with the use of $a$, an, the, and zero article. The errors found can also be grouped into omission and addition.

Based on the data, 12 sentences are incorrect due to the misuse of articles. For example,

\section{(4) Indonesia is beautiful country.}

The example above presents the omission of the articles from a sentence. The sentence is incorrect because the object of the sentence is singular (country), and it is a general statement, thus it requires an article $a$. The correct sentence should be Indonesia is a beautiful country. 
(3) My father is driver.

The sentence is incorrect because the object of the sentence is singular (driver), and it is a general statement, thus it requires an article $a$. The correct sentence should be My father is $\underline{a}$ driver.

(4) Alex eats a mango, and Alan eats a apple

The sentence is incorrect because the noun apple starts with a vowel sound $a$, thus it requires an article an instead of $a$. The correct sentence should be Alex eats a mango, and Alan eats an apple.

(6) Nina drinks a tea.

The example above illustrates the addition of articles when it is not necessary. The sentence is incorrect because the sentence does not require an article. In addition, the noun tea is an uncountable noun, which cannot be preceded by singular definite articles a/an. Instead, it requires the presence of a unit of measurement - a measure word. The correct sentence should be Nina drinks tea or Nina drinks a cup of tea.

\section{Spelling}

Some of the sentences made by the students contain mispelled words. For example,

(1) Because she arrived before the evenwas done, she could join with her friends.

This sentence is a complex sentence consisting three clauses:

1st clause: Because she arrived

2nd clause: before the even was done

3rd clause: she could join with her friends.

The second clause is syntactically incorrect as the subject is missing. The clause structure should be subordinate conjunction+subject+verb. The possible word to fill in the gap is event instead of even.

event(n) a thing that happens, especially one of importance; a planned public or social occasion

even (adv) used to emphasize something surprising or extreme.

The complete sentence would be:

Because she arrived before the event was done, she could join with her friends.

In this sentence, she was present at the event before it was finished, therefore she could meet her friends. 
(2) I am late because my mothercicle was broken.

This sentence is a complex sentence consisting of two clauses:

1st clause: I am late

2nd clause: because my mothercicle was broken

The sentence is syntactically correct as it has the complete features of a complex sentence.

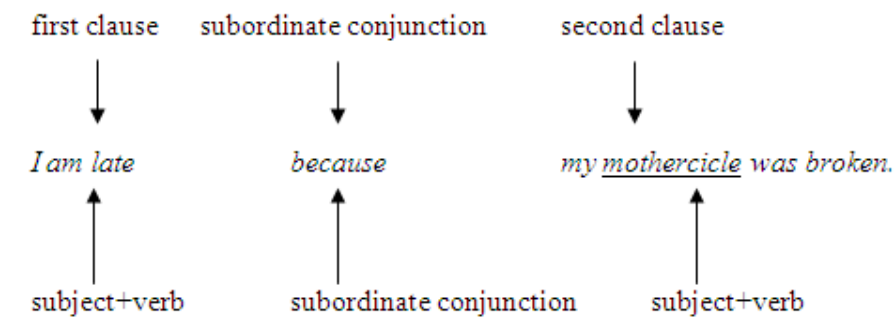

However, the second clause is semantically incorrect as the word mothercicle is lexically unknown. It has no meaning unless it is changed into another word, for example motorcycle.

motorcycle (n) a two-wheeled vehicle that is powered by a motor and has no pedals.

Thus, the sentence would be I am late because my motorcyle was broken.

\section{Impact of Errors}

Despite the errors found in the 123 incorrect sentences from the data, the impact to the meaning, in fact is not significant. The subject verb agreement, for instance, does not affect the message conveyed by the writer.

For example,

(1) Riri go to campus

This sentence is syntactically incorrect and should be Rini goes to campus. However, semantically, the meaning is still acceptable.

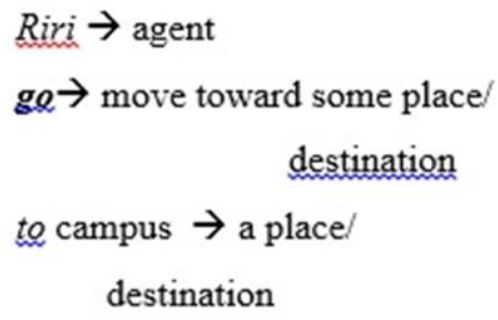

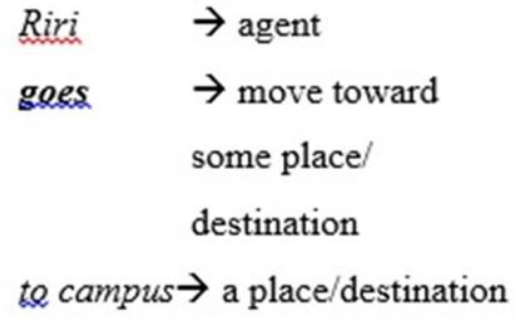


(2) I go to the party last night

This sentence is syntactically incorrect and should be changed into I went to the party last night. However, the sentence is semantically acceptable because the meaning does not change.

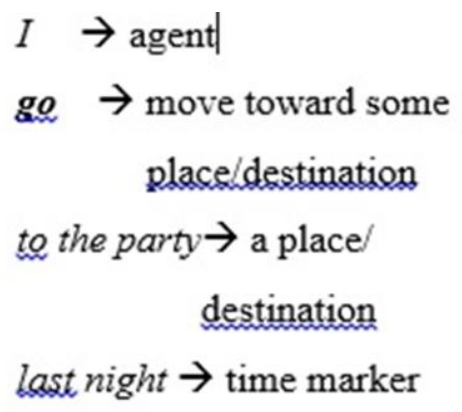

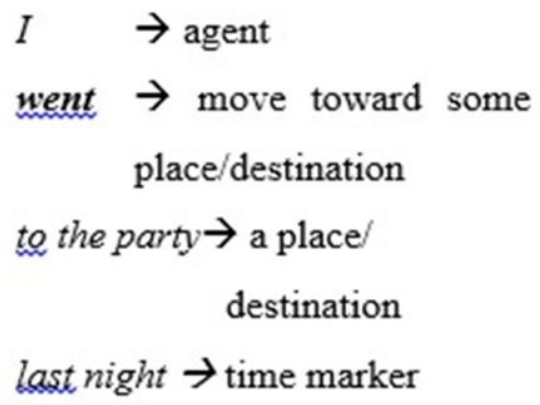

Nevertheless, there is one sentence which is incorrect due to two errors: subject verb agreement and ambiguity.

(3) My mom like banana, but I'm not like that.

This sentence is incorrect because the subject is singular, but the verb is plural. The correct sentence should be My mom likes banana, but I'm not like that.

However, there is another problem in this compound sentence, which is the second clause I'm not like that. This clause is ambiguous because the word "like" has two possible meanings:

like (adj) having similar qualities or features or in similar situation

like (v) to enjoy something or to find something pleasant

Thus, the sentences have two possible meanings.

(a) The "I" is not like that. (he has different favorite fruit)

(b) The "I" does not like that. (the speaker does not like the fact that his mom likes banana)

If the writer wants to convey the meaning (a), the clause is syntactically correct. The writer wants to convey the message that he has different situation with his mom. His mom like banana, but he does not. Meanwhile, if the writer wants to convey meaning (b), the clause is syntactically incorrect. The verb like cannot be preceded by be or be not. Instead, the verb like can be preceded by auxiliary does/do/does not/do not. Thus, the clause should be I do not like that.

\section{CONCLUSION}

The patterns of the errors are spread into eleven types of errors, including verbs, articles, spelling, adjectives, preposition, sentence structure and ordering, word formation, word 
selection, noun, pronoun, and ambiguous communication. It indicates that the students, despite the fact that they have learned English for many years, still have inadequate proficiency in making correct sentences. The most dominant errors are in terms of subject verb agreement and the consistency of the tenses. This indicates that the students' proficiency of subject verb agreement is still weak. The errors did not give significant impact to the meaning. However, in small chances, the errors may trigger ambiguity when the errors occur in certain words which have more than one meaning. Given the fact that the present study focused on students' errors in making written sentences which is only one aspect in English skills, especially writing, further research that explores more comprehensive instruction in a broader context integrating teachers' attitudes and students learning strategies is necessary. When taken together, studies investigating the cause of errors and ways to solve them could provide a framework for improving quality in higher education.

\section{REFERENCES}

Abdullah, Y., Yunus, M., Hashim, Harwati. (2019). Error Analysis in ESL Writing. Asia Proceedings of Social Sciences, 4: 91-93. 10.31580/apss.v4i1.605.

Ananda, R., Gani, S.A., Sahardin, R. (2014). A Study of Error Analysis fromStudents'Sentencesin Writing. Studies In English Language And Education Journal, 1 (2): 81-95.

Bennui, P. (2008). A study of L1 interference in the writing of Thai EFL students. Malaysian Journal of ELTResearch, 4: 72-102

Bumroongthai, G. (2011). An error analysis in English paragragh writing by students of the faculty of liberal arts, Rajamangala University of Technology Phra Nakhon, Research Report, Rajamangala University of Technology Phra Nakhon, Bangkok, Thailand.

Chandler, D. (2003). The Act of Writing: A Media Theory Approach. Prifysgol Cymru Aberystwyth: University of Wales

Corder, S. P. (1981). Error Analysis and Interlanguage. Oxford: Oxford University Press.

Crystal, D. (1999). The penguin dictionary of language. London: Penguin.

Dulay, H. C., Burt, M.K., Krashen, S.D. (1982). Language two. New York: Oxford University Press. 
Hammil, Donald D. (1975). Teaching Children with Learning and Behaviour Problems. Boston: Allyn and Bascon.

Hengwichitkul, L. (2006). An analysis of errors in English abstracts translated by Thaiuniversity graduate students. Unpublished Master Thesis, Srinakharinwirot University,Bangkok, Thailand.

Herdiansyah, H. (2012). Metodologi Penelitian Kualitatif untuk Ilmu-Ilmu Sosial. Jakarta: Salemba Humanika

Heydari, P. \& Bagheri, M. S. (2012). Error analysis: Sources of L2 learners' errors. Theory and Practice in Language Studies, 2(8): 1583-1589.

Hinnon, A. (2004). Common errors in English writing and suggested solutions of Thai university students. 31(2): 165-180.

Huang, S. J. (2006). A case study of EFL students' writing errors on a web-based writing program. Paper presented at International Conference \& Workshop on TEFL and Applied Linguistics, Ming ChuanUniversity, China.

James, C. (1998). Errors in language learning and use: Exploring error analysis. New York: Routledge.

Jenwitheesuk, T. (2009). A study of persisted syntactic errors in writing of the 3rd year students of English for international communication program. Paper presented at International Conference on the Role of University in Hands-on Education, Rajamangala University of Technology Lanna, Thailand.

Kaweera, Ch. (2013). Writing error: A review of interlingual and intralingual interference in EFL context, English Language Teaching, 6(7), 9-18.

Khansir, A. A. (2013). Error analysis and second language writing. Theory and Practice in Language Studies, 3(2): 363-370.

Moleong, L. J. (1998). Metodologi Penelitian Kualitatif. Bandung: PT. Remaja Rosdakarya Mardalis. (2003). Metode Penelitian. Jakarta: Bumi Aksara

Mohammad, S., \& Bahrami, A. (2018). An error analysis of journal papers written by Persian authors. In H. Groth (Ed.). Cogent Arts \& Humanities, 5:1. 
Mungungu, S. S. (2010). Error analysis: Investigating the writing of ESL Namibian learners. Master Thesis, University of South Africa, Pretoria.

Richards, J. C. (1974). Error analysis: Perspectives on second language acquisition. London: Longman.

Runkati, K. (2013). Organizational patterns and common mistakes in English researchabstracts. Unpublished Master Thesis, Prince of Songkla University, Songkhla,Thailand.

Sari, D. (2019). An Error Analysis on Student's Translation Text. Eralingua: Jurnal Pendidikan Bahasa Asing dan Sastra, 3:10.26858/eralingua.v3i2.8658.

Sermsook, K., Liamnimitr, J., Pochakorn, R. (2017). An Analysis of Errors inWritten English Sentences: A Case Study of Thai EFL Students. English LanguageTeaching Journal, 10 (3)

Surachmad, W. (1982). Pengantar Penelitian Ilmiah. Bandung: Tarsito

Wahyuni, S. (2014). Error Analysis of Student'sFree Writing (A Descriptive Study at theEnglish Department of STKIP Bina Bangsa). STKIP Bina Bangsa Getsempena: Getsempena English Education Journal, 1 (2). 